\title{
APPROPRIATING BRUNEI'S WATER VILLAGE AS A TOURISM PRODUCT: AN ANALYSIS OF PRINTED TOURISM BROCHURES, GUIDEBOOKS, AND TOURIST MAPS
}

\author{
${ }^{1}$ Amalina Khalid \& ${ }^{2}$ Hanafi Hussin \\ ( First author, ${ }^{* *}$ Corresponding author) \\ ${ }^{1}$ Department of Anthropology and Sociology \\ ${ }^{2}$ Department of Southeast Asian Studies \\ Faculty of Arts and Social Sciences \\ University of Malaya \\ (mal.abdkhalid@gmail.com, hanafih@um.edu.my) \\ DOI: https://doi.org/10.22452/brj.vol12no1.5
}

\begin{abstract}
The government of Brunei Darussalam has focused more on developing its tourism industry in recent years. One of its primary clusters for tourism development, as stated in the government's five-year tourism master plan (20122016), is Kampong Ayer or the Water Village. The current tourism master plan (2016-2020) also highlights Kampong Ayer as Brunei's main attraction site in the country. This paper aims to discuss how Kampong Ayer has been appropriated into a tourist attraction site as represented in printed tourism promotional materials, i.e., tourism brochures, guidebooks, pocket guides, and tourist maps. This paper focuses on linguistic cues, and visual representations of Kampong Ayer and the analysis is based on using a multimodal discourse framework. Findings show that the Water Village has been appropriated for tourism consumption through six main themes: i) history; ii) modern and traditional lifestyle; iii) size of Kampong Ayer; iv) must-do's and highlights list; v) spatial division of land and water; and vi) Kampong Ayer's links to other tourist sites.
\end{abstract}

Keywords: Kampong Ayer, appropriation, tourism promotional materials, linguistic cues, visual images 


\section{Introduction}

Kampong Ayer, Brunei Darussalam's famous Water Village is one of the Sultanate's greatest landmarks. According to the national census of 2012, the water village is home to some thirteen thousand residents (Oxford Business Group, 2017). The Italian scholar and traveler, Antonio Pigafetta, dubbed Kampong Ayer as "Venice of the East" when he visited Brunei in the $16^{\text {th }}$ century. It was also through Pigafetta's written historical accounts, among others, which confirms Kampong Ayer (which was then equated to Brunei) to be one of the wealthiest Malay kingdoms during the $16^{\text {th }}$ and $17^{\text {th }}$ centuries. Today the Water Village is still a living community, with its residents going about their everyday life being masked by the traditional wooden stilt houses above the Brunei River. Modernity cannot be denied; as with time, this historical residential area has gone through major changes while still preserving its traditional atmosphere. Thus, making it one of Brunei's favorite tourism spots. Kampong Ayer has been used or appropriated in almost all of tourism promotional brochures on Brunei Darussalam due to its status as Brunei's most iconic national landmark.

Furthermore, its location in the heart of the city also plays a central role in attracting tourists all over. Although Kampong Ayer has been the center of attraction for travel and tourism-related activities, the study on the narratives of Kampong Ayer advertising and promotion on printed materials are lacking. This paper thus aims to discuss how Kampong Ayer has been appropriated to become one of Brunei's most visited tourist sites in the country. Representations of the water village using linguistic and visual elements in tourism brochures, guidebooks, and tourist maps are analysed in this research, by focusing on the appropriation of Kampong Ayer in the promotional materials. Six main themes were discovered; historical, modern and traditional lifestyle, size of Kampong Ayer, must do's and highlights, a spatial division of land and water, and its links to other significant tourist sites. These themes contribute to the appropriation of Kampong Ayer in promotional materials in attracting visitors.

\section{Tourism Discourse}

Many scholars and institutions have used various definitions of tourism. The term tourism is problematic as no agreed universal definition can accommodate all the criteria or characteristics of what constitutes 'tourism.' Furthermore, tourism changes over time; what characterises it five decades ago may not be applicable today. However, most scholars have agreed that tourism can be 
defined as a set of activities that involve long or short journeys and temporary stays of the trip with the aim of having leisure and recreational purposes (Smith, 1989; Lanfant, 1993; Dredge \& Jenkins, 2007; Urry, 2002). According to the United Nation's World Tourism Organization tourism has become one of the world's fastest growing economic sectors. Tourism accounts for $10 \%$ of the world's GDP, as well as provides one out of ten jobs worldwide (United Nations World Tourism Organization, 2017). For many developing countries, tourism has provided multifold economic and employment benefits. Tourism thus provides a highly competitive market for hosts to attract visitors to their own "unique" countries.

Tourism discourse is thus packed with the language of persuasion as people try to convince potential visitors to become actual visitors via media such as through printed promotional materials, magazines, books, the Internet, televised communications and so forth. According to Edensor (2001), one of the functions of tourism promotion is to portray the beautifulness and uniqueness of a certain place. Language thus plays an important role in constructing the destination image or representation of the place to make it touristic (Jaworski \& Pritchard, 2005; MacCannel, 1976). Language, aural, spatial, and visual resources are all part of the greater tourism discourse in marketing and promotion of any destination.

Scholars such as Manca (2016), Palmer (1999), Dann (1996), and Adams (1984) argue that tourism promotions not only promote differences and uniqueness but also serve to maintain and perpetuate a particular ideology, especially through the role of language and various communication modes. Tourism brochures, guidebooks, tourist maps and other tourism promotional materials thus play an important role in navigating and shaping the tourists' images of a potential destination. As stated by Jokela and Raento (2012, p. 55) "Tourists like brochures, for they are inexpensive (free), accessible, and easy to carry around. Their images inform about a destination at one glance. They also reinforce place-bound stereotypes and identities and tell about the values and ideologies of their producers and consumers." In a study of Malaysian tourism brochures, Hanita Hassan (2014) noted that Malaysian tourism brochures portray five cultural elements; people of different ethnic groups, festivals, traditional lifestyles, traditional music and dance. 


\section{Methodology}

The set of data used for this research includes tourism promotional materials collected from various travel agencies, tour operators and government agency which totals up to twenty items. These include traveller's mini guides, pocket guides, walking tour map, and promotional tourism brochures. These materials were collected in random at Brunei's Tourist Information Center, Bandar Seri Begawan, in early 2017. A multimodal discourse analysis (Kress \& van Leeuwen, 2001) was conducted for these promotional materials as the research focuses specifically on the language cues and visual images in representing the Water Village. A multimodal analysis allows various modes of communicative methods (aural, textual, linguistic, visual images) in the tourism discourse to be qualitatively evaluated. In advertising places, these different modes are very important as noted by Dann (1996, p. 2):

...tourism, in the act of promotion, as well as in the accounts of its practitioners and clients, has a discourse of its own. Seen in this light, the language of tourism is thus a great deal more than a metaphor. Via static and moving pictures, written texts and audio-visual offerings, the language of tourism attempts to persuade, lure, woo and seduce millions of human beings, and, in doing so, convert them from potential into actual clients.

\section{Appropriation through Linguistic and Visual Modes}

The findings of this research show that Kampong Ayer is appropriated in the promotional materials through six exhaustive themes: i) Kampong Ayer's historical importance; ii) the coexistence of both traditional and modern lifestyles; iii) importance of 'size' of Kampong Ayer in differentiating Brunei's Water Village from the rest of the Malay 'water-worlds'; iv) the inclusion of Kampong Ayer in the must do's and highlights list; v) spatial division of land and water, and vi) by representing Kampong Ayer as accessible to and fro other significant tourist attraction sites in the city of Bandar Seri Begawan. These six themes are further explained below.

\section{Historical Significance of Kampong Ayer}

History plays a very significant role in promoting Kampong Ayer as a tourist destination in showing aspects of the Brunei Malay culture for the water village 
is believed to be in existence since the fifth century (Mohd. Raduan Mohd Ariff \& Mohd. Sharir Mohammad Raduan, 2015). The beginning of Brunei Darussalam could be traced back to Kampong Ayer itself. According to Abdul Latif Ibrahim (1996), Kampong Ayer was the country of Brunei in itself before the twentieth century. The word Kampong Ayer (or Water Village), in fact, only existed or been used in 1910 onwards when residents started moving inland from the Water Village (Abdul Latif Ibrahim, 1996, p. 283). Kampong Ayer was synonymous to Brunei, vice versa. It was only during British administration when the British Residential System (1906-1959) was set up that residents of Kampong Ayer started moving inland, which then finally gave rise to the word "Kampong Ayer" (Water Village). Buildings that remained on the water were referred to as Kampong Ayer, and those on land were then referred to as Brunei Town (today's Brunei capital, Bandar Seri Begawan). Antonio Pigafetta, the Italian traveller and scholar who visited Brunei in 1521, noted a vivid account of Brunei (Nicholl, 1975, p. 10):

That the city is entirely built on salt water, except of the king and certain chiefs. It contains twenty-five thousand hearts (families). The houses are all constructed of wood and built up from the ground on tall pillars. When the tide is high, woman go in boats through the settlement selling articles necessary to maintain life; there is a large brick wall in front of the king's house with towers like a fort in which were mounted fifty-six bronze pieces and six of iron.

During the $16^{\text {th }}$ and $17^{\text {th }}$ century, the city of Brunei (Kampong Ayer) was regarded as one of the greatest ports in the Malay Archipelago (Abdul Aziz, 1996). The outstanding commercial role played by Kampong Ayer is backed up by archaeological investigations which revealed the existence of ceramics and coins from T'ang (618-907), Sung (960-1127) and Ming (1368-1643) dynasties (Harrison, 1970). Below are two extracts showing the use of Kampong Ayer as a historical resource for tourism promotion.

\section{Extract 1}

Historic Sites:

Kampong Ayer (M2/e4)

A historic settlement still vibrant with life in the $21^{\text {st }}$ century, the Kampong Ayer (water village), is a township of multi-coloured houses built on stilts over the Brunei River. Having been in continuous occupation for at least 600 years, this 
tourist hotspot is home to more than 20,000 people. Made up of 42 separate villages or kampungs, it is the largest and best preserved such village in Southeast Asia.

\section{Extract 2}

The famed water village, which you have heard so much about, is located in the middle of town. It has been said that the Brunei River was the wellspring from where life first emerged in Brunei many centuries ago. Kampong Ayer, Asia's own 'Waterworld', or 'Venice of the East' as it is romantically referred to a remnant of ancient Brunei.

Other linguistic cues that have been used repeatedly to show Kampong Ayer's historical significance are such as: "Water Village is Southeast Asia's oldest functional settlement", "Original Venice of the East", "Historic water village", "Historical settlement", "Six hundred years of recorded history lie within these precincts", "Embark on a historical journey". Pictures used in the promotional materials also highlights the old Kampong Ayer, such as the black and white picture of the Water Village as found in one of the guidebooks (Figure $1)$.

\section{Traditional and Modern Lifestyles of Kampong Ayer}

The water village is home to traditional lifestyles, where traditional socioeconomic and socio-cultural practices inherited generationally can still be observed. Fishing, boat-making, and handicrafts productions could easily be found in Kampong Ayer. The community of over four thousand wooden houses on stilts also gives a traditional environment for visitors when compared to the modern concrete houses on the land area. However, there are parts of Kampong Ayer that have gone through major transformations, such as the sixty-five-ecofriendly housing project in which modern building materials were used instead of wood. The walkways of this area are also cemented instead of the normal wooden boardwalks. To walk around Kampong Ayer, one would get the sense that it is a traditional community living in modern times. People who reside in Kampong Ayer are not a backward community, as one would have assumed due to its traditional appearance. Residents of Kampong Ayer enjoys similar comforts felt by people who live on lands, such as television, air conditioning, and other modern amenities (Azman Ahmad, 2013). Schools, police station, fire station, restaurants, and other structural facilities could also be found in the water village. Some scholars (Jones, 1997; Saadiah Tamit, 2009; Azman Ahmad, 2013) 
have to an extent argued that Kampong Ayer is transforming so drastically that its traditional lifestyles are disappearing due to modernity. The promotional materials use the contestation between modern and traditional lifestyles to attract tourists to the Water Village. Below are some examples of mixing tradition with modern living in the promotional materials.

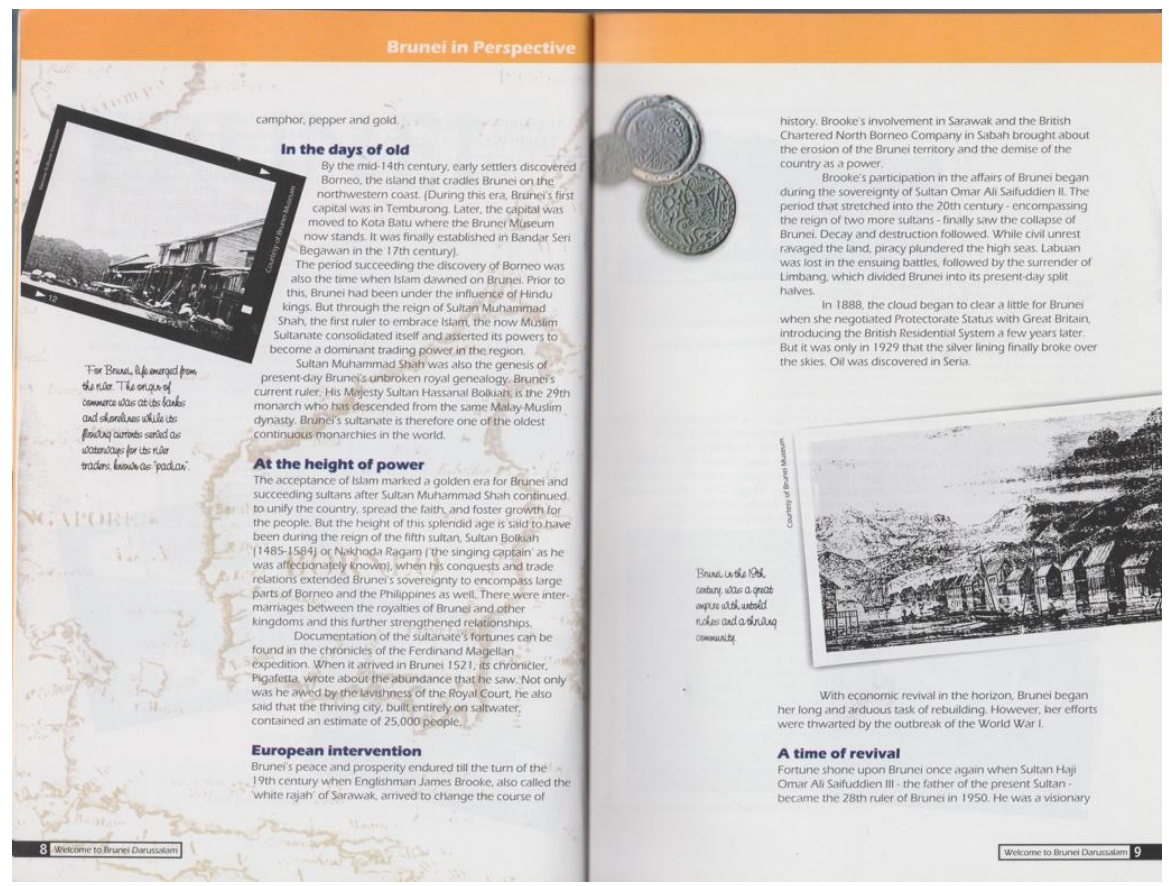

Figure 1: Old pictures of Kampong Ayer shown in a travel guidebook (Source: Welcome to Brunei Darussalam [2000].)

The followings are excerpts from the promotional materials:

A historic settlement still vibrant with life in the $21^{\text {st }}$ century, the Kampong Ayer (water village), is a township of multi-coloured houses built on stilts over the Brunei River. Having been in continuous occupation for at least 600 years, the tourist hotspot is home to more than 20,000 people. [...] Were it not for the television antennae bristling on the roofs, you could almost believe that you had walked into the pages of a history book when Brunei's people depended on the sea and river for their livelihood. However, this community is no inert relic of the past, and the homes feature electricity, running water and Internet 
access. There are schools, mosques, fire stations, police stations, restaurants, and shops.

The highlighted texts show how Kampong Ayer is portrayed to be both a historical place and yet are equally developed and modern as with the rest of the city. Although Kampong Ayer has existed for more than six hundred years, the Water Village is not simply a picture of the past but is an evolving community with modern facilities such as the television and the Internet. The short quotes below also show how traditional products are promoted, such as local cakes. 'Modern' and 'traditional' are the two linguistic cues that have repeatedly been used in the various promotional materials:

Take a ride on the water taxi and experience the local life in $\mathrm{Kg}$. Ayer, enjoy some local cakes and tea and discover the unique mix of traditional and modern lifestyle.

$\mathrm{Kg}$. Ayer is a historic settlement right in the middle of $21^{\text {st }}$ century Bandar Seri Begawan.

The contrast (or mixing) between modern and traditional lifestyle in the Water Village is used in attracting tourists. The location of the Water Village in

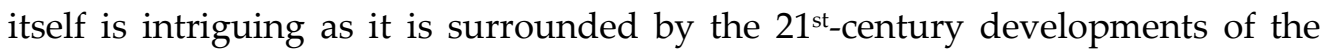
city, Bandar Seri Begawan.

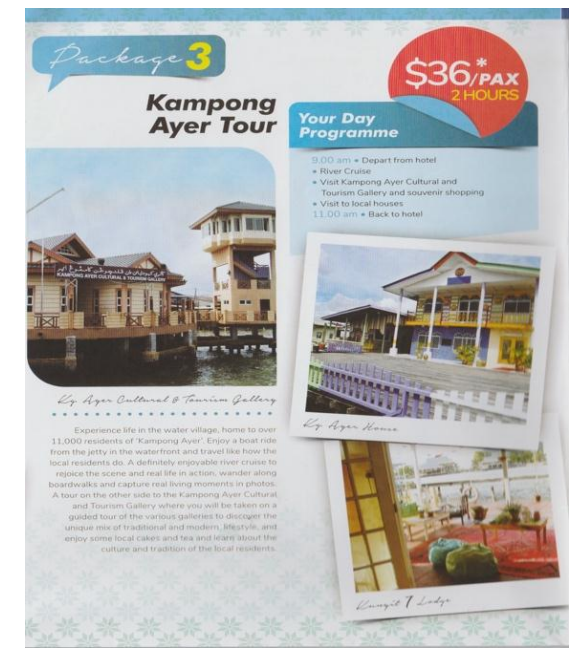

Figure 2: Modern structures in the Water Village as shown in tourist brochures (Source: Bandar Seri Begawan and Kg Ayer Tour Packages [2017].) 
On the water, you have these wooden-built houses, seemingly traditional, and in contrast, you have concrete shop buildings on land surrounding the water village equating to modern developments. The visual images used in the promotional materials highlight this contrast, showing two contrasting developments as shown in the pictures below (Figure 2 \& Figure 3).

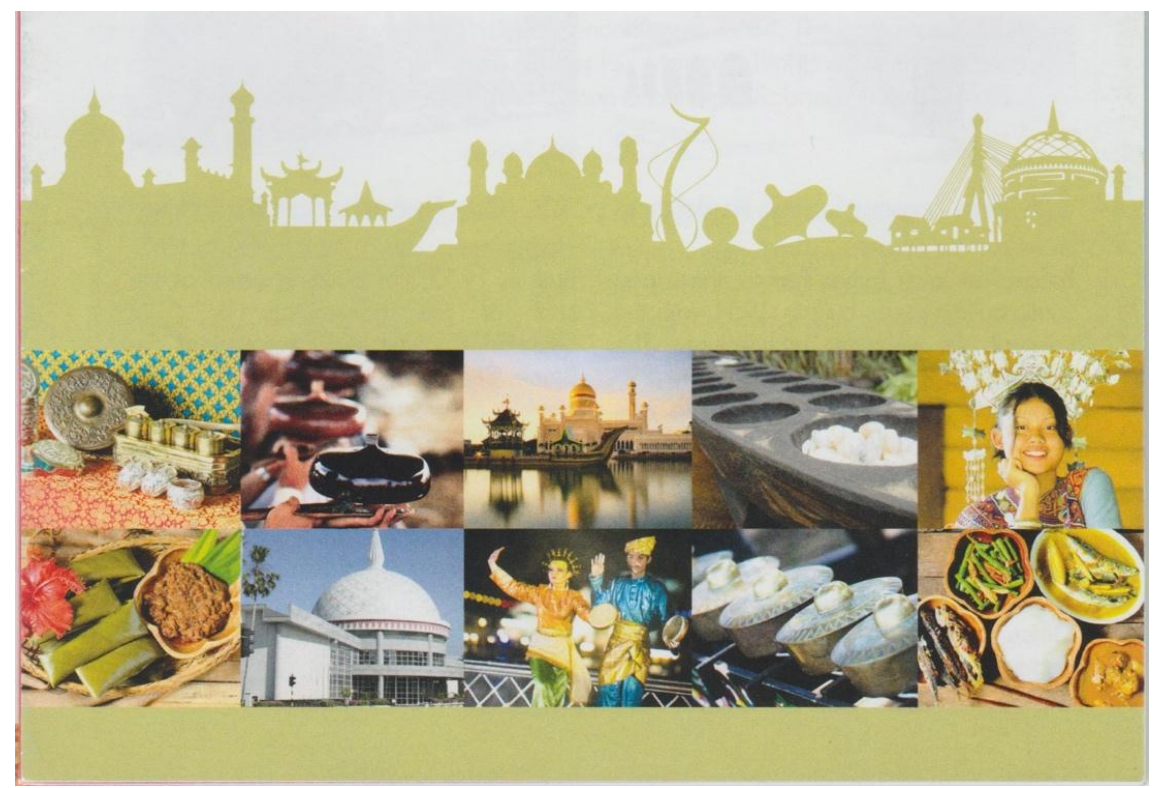

Figure 3: Traditional cultural elements of Brunei

(Source: "Bandar Seri Begawan: ASEAN City of Culture 2016-2017” [printed material].)

\section{Size of Kampong Ayer}

The size of Kampong Ayer is one of the major selling themes of it being a tourist attraction. While you can find other almost similar water villages throughout Southeast Asia, Brunei's water village takes pride on being one of the biggest water villages in the world, and this has been stated in the promotional materials on Kampong Ayer. The size of the population in Kampong Ayer is also significant in promoting the area, in which the earliest ever recorded number of population was twenty-five thousand hearths by the Italian traveller Antonio Pigafetta in 1521. According to the latest national census for Kampong Ayer stated that the number of population in Kampong Ayer has dwindled to thirteen thousand one hundred and sixty-two persons in 2012. However, the size of the 
population in the promotional materials still highlights some twenty thousand people and above.

Some 4,000 buildings stretching along the river, connected by $30 \mathrm{~km}$ of wooden walkways.

Water village is one of Brunei's heritage jewels, the largest settlement on stilts. Also the cultural heartland of the Brunei Malay.

Hail a water taxi to take you through the narrow waterways of Kampong Ayer - a township of multi-coloured houses. The largest water village in Southeast Asia.

\section{World's largest water village, over 30,000 inhabitants.}

River Cruise along Brunei River. Go on a scenic boat ride around the biggest Malay water village in the world and visit a local home to observe the daily livelihood of typical residents of the houses on stilts in the Brunei river.

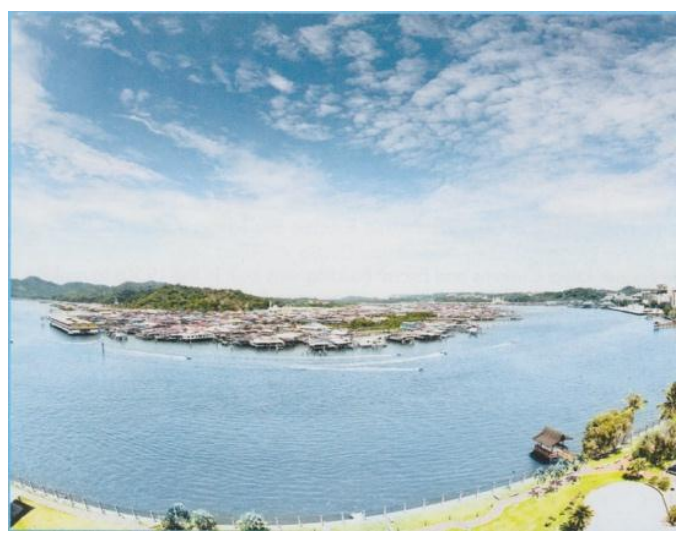

Figure 4: Panoramic view of Kampong Ayer

(Source for Figures 4 and 5:

"Bandar Seri Begawan: ASEAN City of Culture 2016-2017" [printed material].)

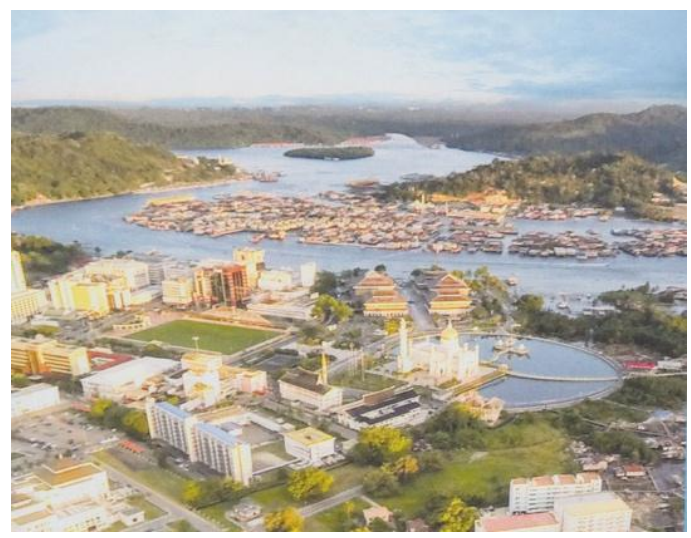

Figure 5: Panoramic view of Kampong Ayer and Bandar Seri Begawan, Brunei's Capital City 
Water villages can be found in other parts of Southeast Asia, such as in Vietnam, Myanmar, and Malaysia. Brunei claims it is Kampong Ayer to be the largest Malay water village in the world, making it significantly different from the rest. The great size of Kampong Ayer is repeatedly shown in the promotional materials by displaying the bird's eye view or a panoramic view of the area such as shown in Figures 4 and 5. The 'size' theme has been used to advertise Kampong Ayer as unique and different from the others, to appropriate the Water Village to be touristic.

\section{Must-Do's and Highlights}

Kampong Ayer appears in all the must do's and highlights lists of the promotional materials, as such, it has elevated the significance of Kampong Ayer as one of Brunei's tourist sites. Must-do's or highlights section of the printed promotional materials puts Kampong Ayer on top of the list of tourist attractions in Brunei. By using the heading 'Must-Do's' or 'Highlights,' it gives people the summary on the places of interests for visitors to the country. In all the brochures collected, Kampong Ayer is featured on the top five lists of places to visit in Brunei Darussalam. This entails the significance of Kampong Ayer to Brunei's tourism industry. As such, it has been appropriated to be a tourism product of the Sultanate. Figures 6, 7 and 8 show Kampong Ayer being featured on the list of highlights and Must-Do's on brochures and mini pocket-guides.

\section{Spatial Division: Land and Water}

The spatial separation between land and water has been used in the promotional materials especially in the visual images presented. The land represents Bandar Seri Begawan, whereas water area (Brunei River) represents Kampong Ayer. The spatial division between land and water highlights the uniqueness of Kampong Ayer. Where land can be equated to modern development, there's another part of Bandar Seri Begawan, the Brunei River that is portrayed to be 'different,' 'unique,' which is Kampong Ayer. Water taxis add to this uniqueness where in almost all of the pictures and descriptions presented in the data analysed, images or mentioning of the water taxi is included, again, highlighting the spatial division between land and water. As water taxis are the main mode of transportation in Kampong Ayer, it serves to highlight the special features of being on the Brunei River, differentiating the space between land and water. Pictures shown in Figure 9, 10 and 11 show the positioning of boats in all 
complementing images, this which can repeatedly be seen in many of the promotional tourism materials.

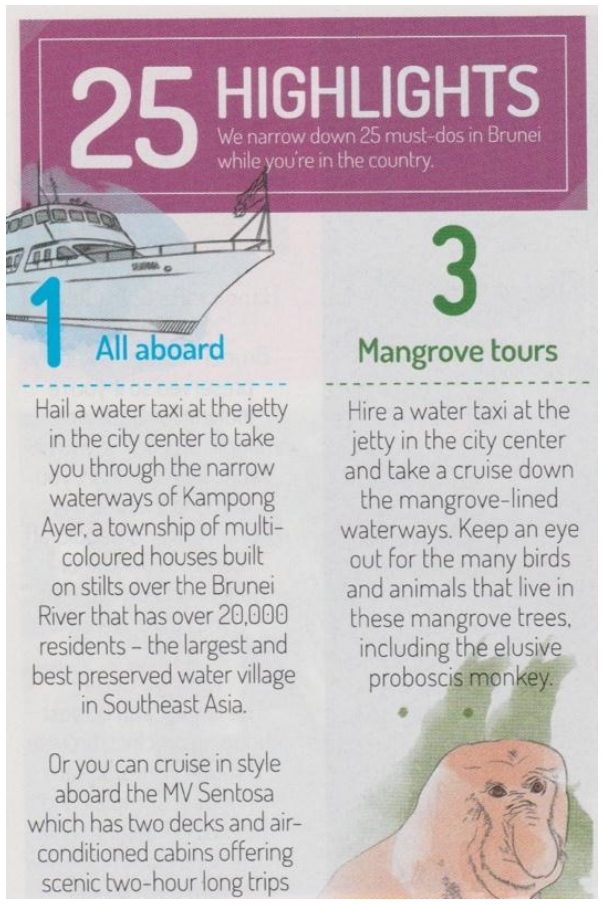

Figure 6: Highlights of Brunei (Source: A Pocket Guide to Brunei Darussalam: Top Picks \& Travel Highlights [n.d.].)

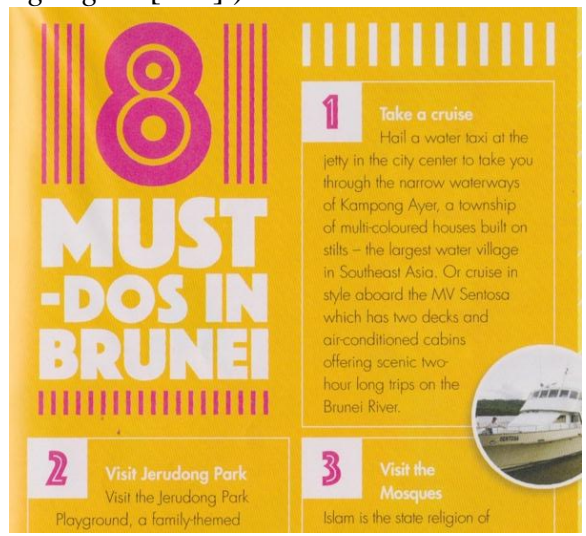

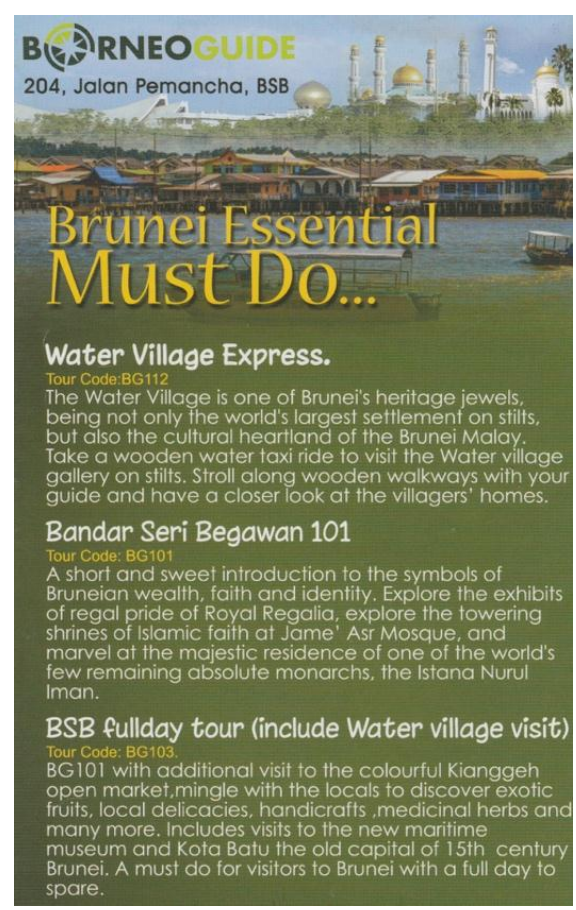

Figure 7: Must-Do List of Brunei as seen on a tourist brochure

(Source: Borneo Guide [printed material].)

Figure 4: Kampong Ayer featured as number one on Brunei's Must-do list (Source: Mini Guide to Brunei Darussalam [n.d.].) 


\section{Links to Other Tourist Sites within the City}

Situated in the heart of Brunei's capital, Kampong Ayer is easily accessible and links to other tourist sites in the city. There are two ways in which the other points of interests can be reached: by boat through Kampong Ayer, and by walking short distances from Kampong Ayer. Brunei river cruise connects Kampong Ayer to other places such as the mangrove forest where visitors can get a chance to watch the endemic Borneo species, the Proboscis monkey. Other places include Kampong Ayer Cultural and Tourism Gallery, Kianggeh Open Market, Omar Ali Saifuddien Mosque, Royal Wharf, Arts and Handicraft Centre, Fish Farms, Jong Batu, Brunei Museum, Istana Nurul Iman (Light of Faith Palace), Brunei Technology Museum, and Brunei Maritime Museum. Figure 12 is "Bandar Walking Map," where the main points of interests within the city can be reached by walking. Areas included in the walking map show Kampong Ayer, Omar Ali Saifuddien Mosque, Taman Sir Omar Ali Saifuddien, the Royal Regalia building (renamed to Royal Regalia Museum in December 2017), Royal Wharf (Dermaga Diraja Bandar Seri Begawan), and others. All of these are linked to Kampong Ayer, which makes the Water Village an even more accessible destination for visitors of the Sultanate.

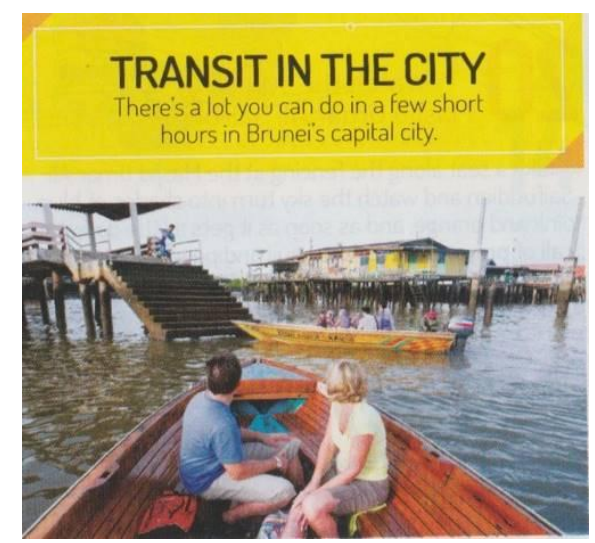

Figure 9: A motorboat passing through Brunei River

(Source for Figures 9 and 10: Mini to Brunei Darussalam [n.d.].)

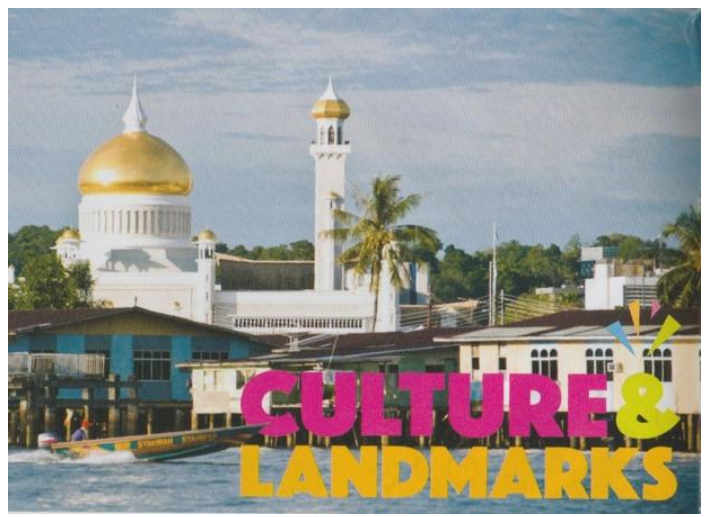

Figure 10: Tourists and passengers seen aboard water-taxis

Guide 


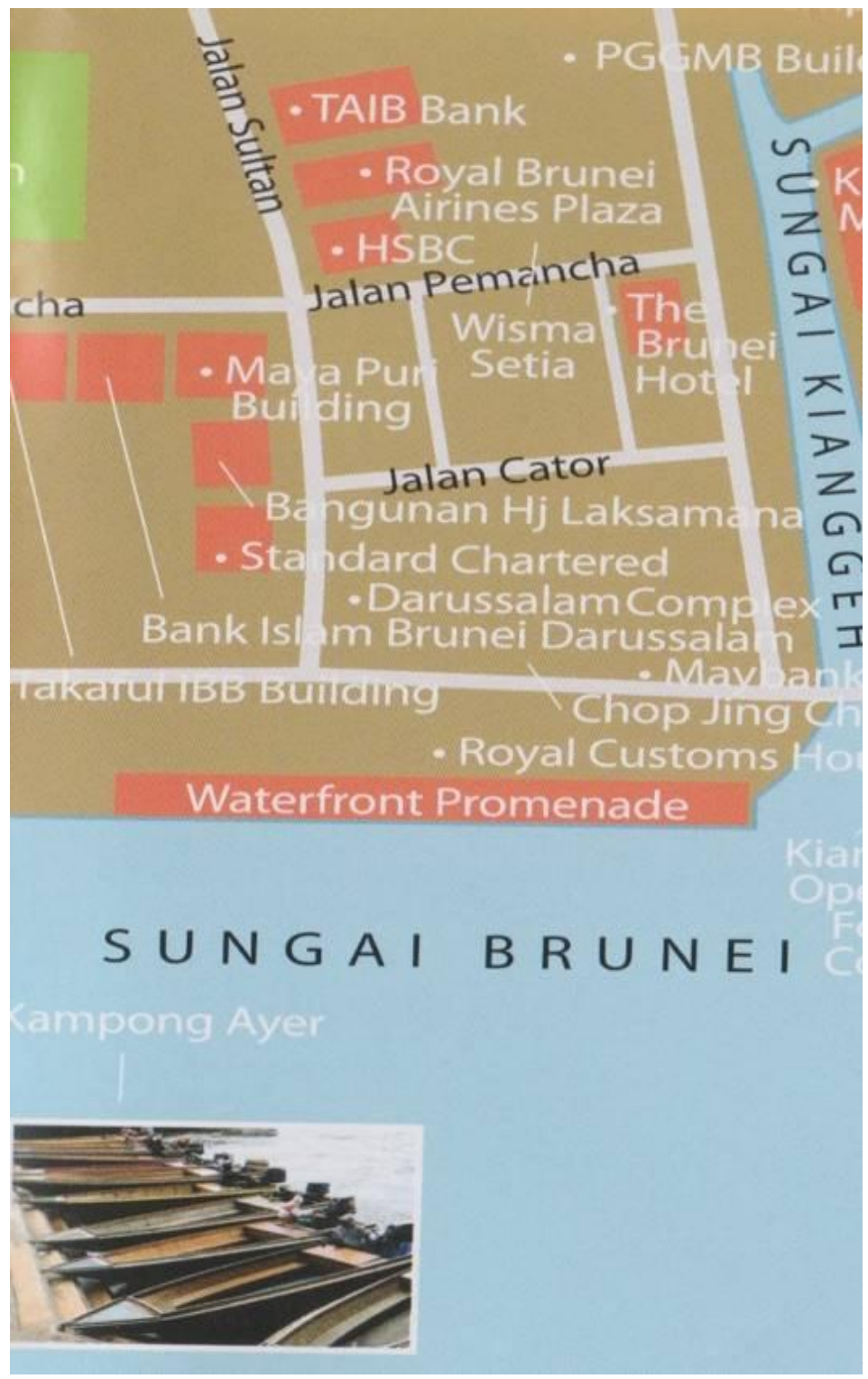

Figure 5: Water Taxis representing Kampong Ayer as shown on the map (Source: Mini Guide to Brunei Darussalam [n.d.].) 


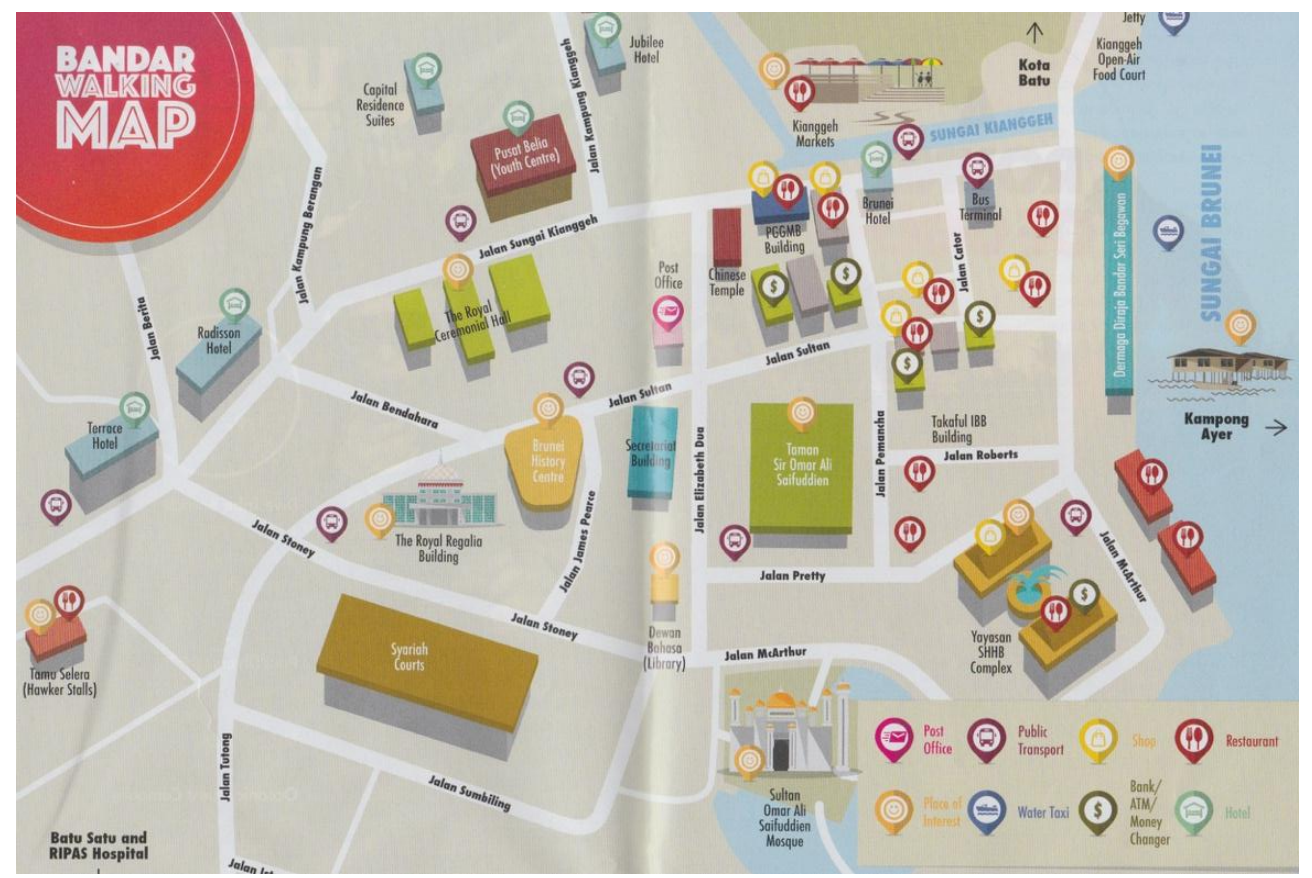

Figure 6: 'Bandar Walking Map' showing places of interest within walking distance in Bandar Seri Begawan

(Source: Mini Guide to Brunei Darussalam [n.d.].)

\section{Conclusion}

In conclusion, Kampong Ayer has been selectively portrayed in the promotional materials through six recurring themes. The six themes that are used to promote Kampong Ayer are: its historical significance, the coexistence of both modern and traditional lifestyles in the Water Village, its great size, the must-do and highlights lists, spatial division of land and water, and the accessibility and links of Kampong Ayer to other tourist attraction sites within Bandar Seri Begawan. All of these themes are significant in steering tourists to visit Kampong Ayer with the use of visual and linguistic cues. Kampong Ayer is constantly being appropriated for tourism purposes by various stakeholders and through various channels. Printed tourism promotional materials are just one aspect or area where Kampong Ayer has been adjusted and portrayed selectively for attracting tourists to the area. 


\section{References}

A Pocket Guide to Brunei Darussalam: Top Picks \& Travel Highlights. (n.d.). Bandar Seri Begawan: CHMP Media.

Abdul Latif Ibrahim. (Ed.). (1996). Kampong Ayer: Warisan, Cabaran dan Masa Depan - Kumpulan Esei yang Pernah diterbitkan 1970-1996. [Kampong Ayer: Heritage, Challenges and the Future - A Collection of Essays that were Published 1970-1996]. Bandar Seri Begawan: Akademi Pengajian Brunei.

Adams, K. (1984). Come to Tana Toraja, “Land of the Heavenly Kings': Travel Agents as Brokers of Ethnicity. Annals of Tourism Research, 11(3), 469-485.

Azman Ahmad. (2013). The Constraints of Tourism Development for a Cultural Heritage Destination: The Case of Kampong Ayer (Water Village) in Brunei Darussalam. Tourism Management Perspectives, 8, 106-113.

Bandar Seri Begawan and Kg Ayer Tour Packages. (2017). Bandar Seri Begawan: Tourism Development Department.

Dann, G. (1996). The Language of Tourism: Sociolinguistic Perspective. Wallingford: CAB International.

Dredge, D., \& Jenkins, J. (2007). Tourism Planning and Policy. Brisbane: John Wiley.

Edensor, T. (2001). Performing Tourism, Staging Tourism: (Re)producing Tourist Space and Practice. Tourist Studies, 1(1), 59-81.

Hanita Hassan. (2014). The Representation of Malaysian Cultures in Tourism Brochures. Procedia Social and Behavioral Sciences, 118, 140-151.

Harrison, T., (1970). The Prehistory of Borneo. Asian Perspectives. 8(13),17-45. Jaworski, A., \& Pritchard, A. (Eds.). (2005). Discourse, Communication and Tourism. Clevedon: Channel View Publications.

Jokela, S., \& Raento, P. (2012). Collecting Visual Materials from Secondary Sources. In T. Rakić \& D. Chambers (Eds.), An Introduction to Visual Research Methods in Tourism (pp. 53-69). New York: Routledge.

Jones, A. (1997). Urban Conservation Issues in Brunei Darussalam: The Case of Brunei's Water Village. Planning Perspectives, 12(4), 457-475.

Kress, G., \& van Leeuwen, T. (2001). Multimodal Discourse: The Modes and Media of Contemporary Communication. London: Arnold.

Lanfant, M-F. (1993). Methodological and Conceptual Issues Raised by the Study of International Tourism: A Test for Sociology. In D. Pearce \& R. Butler (Eds.), Tourism Research: Critique \& Challenges (pp. 70-87). London: Routledge.

MacCannel, D. (1976). The Tourist: New Theory of Leisure Class. Berkeley: University of California Press. 
Manca, E. (2016). Persuasion in Tourism Discourse: Methodologies and Models. Newcastle upon Tyne: Cambridge Scholars Publishing.

Mini Guide to Brunei Darussalam. (n.d.). Bandar Seri Begawan: Ministry of Primary Resources and Tourism.

Mohd. Raduan Mohd Ariff, \& Mohd. Sharir Mohammad Raduan. (2015). Tourism Industry in Brunei Darussalam: An Assessment of its Developability. Borneo Research Journal, 9(1), 101-119.

Nicholl, R. (1975). European Sources for the History of Sultanate of Brunei in the Sixteenth Century. Bandar Seri Begawan: Brunei Museum.

Oxford Business Group. (2017). Development plans for Brunei Darussalam's Bandar Seri Begawan to create new opportunities. Retrieved December 12, 2017, from https://oxfordbusinessgroup.com/overview/renovations-underway-development-plans-capital-mean-new-opportunities

Palmer, C. (1999). Tourism and the Symbols of Identity. Tourism Management, 20(3), 313-321.

Saadiah Tamit. (2009). Brunei Kampong Ayer: Facing the Development. Borneo Research Journal, 3(1), 209-219.

Smith, V. (1989). Hosts and Guests: The Anthropology of Tourism. Philadelphia: University of Pennsylvania Press.

United Nations World Tourism Organization. (2017). Why Tourism Matters. Retrieved December 12, 2017, from http://www2.unwto.org/content/whytourism

Urry, J. (2002). The Tourist Gaze. London: SAGE Publications.

Welcome to Brunei Darussalam: The Complete Traveller's Guide. (2000). Bandar Seri Begawan: Brunei Press Sdn. Bhd. 